\title{
PREPARATIONS OF COMPOSITE CONCRETES USING IRON ORE TAILINGS AS FINE AGGREGATES AND THEIR MECHANICAL BEHAVIOR
}

\author{
PRIPRAVA KOMPOZITNIH BETONOV Z UPORABO FINIH \\ AGREGATOV IZ ODPADKOV ŽELEZOVE RUDE IN NJIHOVE \\ MEHANSKE LASTNOSTI
}

\author{
Yufeng Jiang, Hao Wang, Yue Chen, Min Ruan, Wen Li* \\ Hubei Polytechnic University, No. 16 Guilin North Road, Xialu District, Huangshi, 435000, Hubei, China \\ Prejem rokopisa - received: 2018-10-13; sprejem za objavo - accepted for publication: 2019-01-11.
}

doi:10.17222/mit.2018.222

\begin{abstract}
Experiments were conducted to determine the utilizability of iron ore tailings from Lingxiang town near Huangshi City in Hubei province of China as a fine aggregate replacement for regular sand in concrete. The mix design was carried out for concrete with 35 grade. The sand was replaced with $(0,10,20,30,40,50$ and 60$) \%$ iron ore tailings, respectively. The results show that the workability of fresh concrete reduced with the increasing of the iron ore tailings. And the workability can decrease significantly when the iron ore tailings are more than $40 \%$. Twenty eight days compressive strength and split flexible strength of the hardened concrete specimens exceeded $35 \mathrm{MPa}$ and $5 \mathrm{MPa}$, respectively, and they reached the maximum when there was $30 \%$ iron ore tailings. Their flex-compression ratio was $1 / 6$ and $10 \%$ higher than that of the control group that used sand as the fine aggregate. The crack resistance of the iron ore tailings concrete was studied at the same time, and the microstructure was observed with an SEM.
\end{abstract}

Keywords: iron ore tailings, fine aggregate, compressive, flex-compression ratio, crack resistance

Avtorji so izvajali preizkuse, da bi ugotovili ali so lahko odpadki železove rude iz Lingxianga pri mestu Huangshi v provinci Hubei na Kitajskem kot fini agregat ustrezna zamenjava za običajni pesek v mešanici za beton. Pripravili so mešanico betona kvalitete 35 (s tlačno trdnostjo $35 \mathrm{MPa})$. Pesek so nadomestili z $(0,10,20,30,40,50$ in 60$) \%$ odpadkov železove rude. Rezultati preizkusov so pokazali, da se je obdelovalnost betonov zmanjševala s povečevanjem vsebnosti odpadkov železove rude. Pri vsebnosti nad $40 \%$ odpadkov železove rude se je obdelovalnost betona drastično zmanjšala. Osemindvajsetdnevna tlačna in upogibna trdnost utrjenih vzorcev betonov je presegla $35 \mathrm{MPa}$ oz. $5 \mathrm{MPa}$ in maksimalne vrednosti so bile dosežene pri betonu, kateremu je bilo dodanih $30 \%$ odpadkov železove rude. Ta beton je imel razmerje med upogibno in tlačno trdnostjo 1:6, kar je bilo $10 \%$ več kot kontrolna skupina, ki je vsebovala samo pesek kot dodatek finega agregata. Istočasno so ugotavljali odpornost izdelanih betonov proti pokanju in opazovali njihovo mikrostrukturo z vrstičnim elektronskim mikroskopom (SEM).

Ključne besede: odpadki železove rude, fini agregati, razmerje med tlačno in upogibno trdnostjo, odpornost proti pokanju

\section{INTRODUCTION}

Ore tailings are the largest solid wastes of the mining and mineral industries. In China, the amount of ore tailings was up to 14.6 billion $t$ at the end of 2013, and Iron Ore Tailings (hereinafter referred to as IOT) is about $50.88 \% .{ }^{1}$ As the largest amount of ore tailings, the utilization of IOT is very difficult, and its low utilization causes the environmental problems of farmland occupation, vegetation destruction, and water pollution. ${ }^{2,3}$ M. A. Onitiri et alinvestigated the effect of particle size and particle loading of iron-ore-tailing-filled epoxy and polypropylene composites on the stiffness and tensile strength. ${ }^{4}$ They found that the stiffness increased with the content of IOT. S. Ullas et al. made masonry units with a mixture of soil, sand and cement with the replacement of $25 \%, 50 \%$ and $100 \%$ IOT. 5 They found the wet compressive strength, water absorption, initial rate of absorption, and linear elongation had no desirable degradation. T. I. Ugama and S. P. Ejeh examined the IOT from Itakpe

*Corresponding author's e-mail:

1xfzzl@126.com mines near Okene in Kogi state of Nigeria as a fine aggregate replacement of sand (RS) for the mortar used for masonry. ${ }^{6}$ A. Shettima et al. also used IOT as fine aggregate to prepare concrete. ${ }^{7-10}$ The tested result shows that $28 \mathrm{~d}$ compressive strength, indirect tensile and flexural strength values of comparable to control the mix when the combination of IOT and river sand is therefore $20 \%$ IOT and $80 \%$. S. Zhao et al. used IOT to replace natural aggregate to prepare ultra-high-performance concrete. ${ }^{11}$ It was found that $100 \%$ replacement of IOT could significantly decrease the workability and compressive strength. When there was no more than $40 \%$ IOT replacement, the mechanical property of the $90 \mathrm{~d}$ standard cured specimen was comparable to that of the control group and that were steam cured for $2 \mathrm{~d}$ (days). The compressive strength decreased by $11 \%$, and the flexural strength increased by $8 \%$. X. Huang et al. used IOT to prepare greener engineered cementious composites (ECCs) with a tensile ductility of 2.3-3.3\%, tensile strength of 5.1-6.0 MPa and compressive strength of 46-57 MPa at the $28^{\text {th }}$ day. ${ }^{12}$ Y. Hou investigated the characteristics of mineral admixture with IOT powder 
Y. JIANG et al.: PREPARATIONS OF COMPOSITE CONCRETES USING IRON ORE TAILINGS ...

Table 1: Chemical component of IOT and cement (\%)

\begin{tabular}{|c|c|c|c|c|c|c|c|c|c|}
\hline Name & $\mathrm{SiO}_{2}$ & $\mathrm{Al}_{2} \mathrm{O}_{3}$ & $\mathrm{Fe}_{2} \mathrm{O}_{3}$ & $\mathrm{CaO}$ & $\mathrm{MgO}$ & $\mathrm{SO}_{3}$ & $\mathrm{~K}_{2} \mathrm{O}$ & $\mathrm{Na}_{2} \mathrm{O}$ & $\mathrm{Loss}$ \\
\hline IOT & 73.85 & 5.92 & 15.4 & 0.48 & 1.20 & $/$ & 1.00 & 1.05 & 5.87 \\
\hline Cement & 21.05 & 6.05 & 3.64 & 63.98 & 2.68 & 0.23 & $/$ & $/$ & 3.24 \\
\hline
\end{tabular}

Table 2: Size distributions of the used materials

\begin{tabular}{|c|c|c|c|c|c|c|c|c|}
\hline Name & Sieve size $(\mathrm{mm})$ & 4.75 & 2.36 & 1.18 & 0.60 & 0.30 & 0.15 & 0.088 \\
\hline NRS & \multirow{2}{*}{ Cumulative percentage $(\%)$} & 8.51 & 22.43 & 44.32 & 62.15 & 90.06 & 96.86 & 100 \\
\hline IOT & & 0 & 1.0 & 2.3 & 7.3 & 37.8 & 98.3 & 99.5 \\
\hline
\end{tabular}

and ground slag in the proportion of $2: 8,4: 6$ and $6: 4 .{ }^{13}$ The results showed that the compressive strength of the concrete decreased with the percentage of IOT powder increasing, because of the low activity of the IOT. K. Shetty et al. prepared self-compacting concrete by partially replacing the cementitious material with red mud (RM) and partially replacing the sand with IOT. ${ }^{14}$ The results showed that the compressive strength and flexural strength were more than the control mix. S. Jian et al. found that IOT could be used to manufacture construction materials due to the high content of iron, and the product required a lower sintering temperature and energy. ${ }^{15}$ At present, the IOT has been widely used in other building materials, which solve the low level utilization of IOT all over the world. ${ }^{16-21}$

Our team makes efforts in the high-value utilization of IOT of Huangshi city, Hubei Porovince, China recent years. $^{22,23}$ This investigation aims to prepare high tensile-compressive strength concrete by changing the ratio of IOT that was used as fine aggregate and the replacement of regular sand.

\section{EXPERIMENTAL PART}

\subsection{Materials}

The ordinary Portland cement (42.5 grade) used in this study is from Huaxin Cement Co. LTD and its chemical components and physical properties are listed in Table 1 and 2, respectively. The IOT containing 15-20\% iron is obtained from Lingxiang Town of Huangshi City, Hubei Province, China. Its apparent density is $2.58 \mathrm{~g} / \mathrm{cm}^{3}$ with a fineness modulus of 0.36 . The XRD pattern of IOT is given in Figure 1, the chemical component in Table 1, and the sieving analysis results in Table 2.

The coarse aggregate has a local source with a maximum size of $31.5 \mathrm{~mm}$ and the apparent density of $2.71 \mathrm{~g} \cdot \mathrm{cm}^{-3}$. The fly ash used in this study was grade II and obtained from Xisaishan Thermal Power Plant Station of Huangshi. The polycarboxylate-based superplasticizer (SP) has about $35 \%$ solid content and a water-reducing rate of about $40 \%$.

\subsection{Instruments}

The following instruments were utilized to perform different experiments in the research: X-ray fluorescence
(XRF) was used for the chemical composition of IOT and cement using a Bruker (Billerica, MA, USA) XRF machine. X-ray diffraction (XRD) analysis was conducted using a Rigaku (Akishima-shi, Tokyo, Japan) XRD machine. Scanning electron microscope (SEM) analysis was performed by Supra 55 VP, ZEISS (Oberkochen, Germany). A compression machine (Jinan, Shandong, China) with $2000 \mathrm{kN}$ capacity was used for compressive of specimens and a flexural machine (Cangzhou, Hebe) with $300 \mathrm{kN}$ capacity for flexural and split tensile tests.

\subsection{Mix proportions and specimen preparation}

\subsubsection{Mix proportion}

Concrete specimens were prepared with the partial replacement of iron ore tailings in this study. Table $\mathbf{3}$ presents 7 kinds of concrete mix proportions, and the first mix was a controlled mix without iron ore tailings. The controlled mix was made for $\mathrm{C} 35$ grade. In the mixture, $10 \%, 20 \%, 30 \%, 40 \%, 50 \%$ of fine aggregate (regular sand) were replaced with iron ore tailings, respectively.

\subsubsection{Preparation and casting of specimens}

The $150 \mathrm{~mm} \times 150 \mathrm{~mm} \times 150 \mathrm{~mm}$ cubes were casted for compressive strength and split tensile strength and $150 \mathrm{~mm} \times 150 \mathrm{~mm} \times 550 \mathrm{~mm}$ beams for flexural

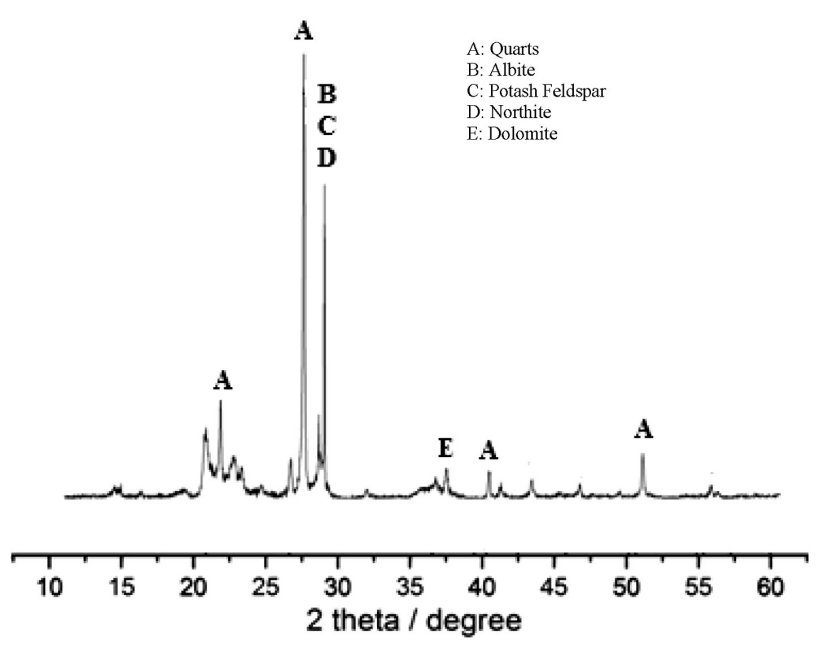

Figure 1: XRD pattern of IOT 
Table 3: Concrete mix designation

\begin{tabular}{|c|c|c|c|c|c|c|c|c|}
\hline Trial No. & $\begin{array}{c}\text { Cement } \\
\left(\mathrm{kg} \cdot \mathrm{m}^{-3}\right)\end{array}$ & $\begin{array}{c}\text { Fly ash } \\
\left(\mathrm{kg} \cdot \mathrm{m}^{-3}\right)\end{array}$ & $\begin{array}{c}\mathrm{IOT} \\
\left(\mathrm{kg} \cdot \mathrm{m}^{-3}\right)\end{array}$ & $\begin{array}{c}\mathrm{NRS} \\
\left(\mathrm{kg} \cdot \mathrm{m}^{-3}\right)\end{array}$ & $\begin{array}{c}\mathrm{CA} \\
\left(\mathrm{kg} \cdot \mathrm{m}^{-3}\right)\end{array}$ & $\begin{array}{c}\mathrm{SP} \\
\left(\mathrm{kg} \cdot \mathrm{m}^{-3}\right)\end{array}$ & $\begin{array}{c}\mathrm{Sp} / \mathrm{B} \\
(\%)\end{array}$ \\
\hline NC & 367 & 53 & 0 & 672 & 1178 & 0.18 & 0.44 & 35.7 \\
\hline 10 IOT & 367 & 53 & 67.2 & 604.8 & 1178 & 0.18 & 0.44 & 35.7 \\
\hline 20 IOT & 367 & 53 & 134.4 & 537.6 & 1178 & 0.18 & 0.44 & 35.7 \\
\hline 30 IOT & 367 & 53 & 201.6 & 470.4 & 1178 & 0.18 & 0.44 & 35.7 \\
\hline 40 IOT & 367 & 53 & 268.8 & 403.2 & 1178 & 0.18 & 0.44 & 35.7 \\
\hline 50 IOT & 367 & 53 & 336.0 & 336.0 & 1178 & 0.18 & 0.44 & 35.7 \\
\hline 60 IOT & 367 & 53 & 403.2 & 268.8 & 1178 & 0.18 & 0.44 \\
\hline
\end{tabular}

strength. After casting, all the test specimens were kept at room temperature for $24 \mathrm{~h}$ and then de-molded. Then these were cured in a standard room at about $20{ }^{\circ} \mathrm{C}$ with a relative humidity of about $95 \%$ for a certain time.

\subsubsection{Properties of fresh concrete and hardened con- crete}

The properties of fresh concrete such as slump and bleeding were conducted according to the Chinese Standard GB-T50080-2011.

\subsubsection{Mechanical properties of hardened concrete}

The compressive strength tests on cubes were performed on the $3^{\text {rd }}, 7^{\text {th }}$ and $28^{\text {th }}$ day. The split tensile tests on the cubes and the flexural strength tests on beams were performed on the $28^{\text {th }}$ day.

\subsubsection{Cracking resistance of hardened concrete}

The $25 \mathrm{~mm} \times 25 \mathrm{~mm} \times 280 \mathrm{~mm}$ beams were cast for cracking resistance, at which both ends copper heads were embedded. The specimens were added with some fiber and cured for $3 \mathrm{~d}$ under standard conditions after being de-moulded. The test was performed under the controlled conditions with a wind speed of $8 \mathrm{~m} / \mathrm{s}$, a temperature of $20 \pm 1{ }^{\circ} \mathrm{C}$ and a humidity of $60 \pm 5 \%$. The original lengths of these samples were measured on the $3^{\text {rd }}, 7^{\text {th }}, 14^{\text {th }}, 28^{\text {th }}$ and $60^{\text {th }}$ day respectively. The numbers, width and length of the cracks on these specimen surfaces were all recorded.

\section{RESULTS AND DISCUSSION}

\subsection{Workability of fresh concrete properties}

\subsubsection{Slump}

Table 4 shows the workability of fresh concrete and the slump loss after $60 \mathrm{~min}$. It can be seen that the initial slump value increased with the increasing IOT content when the IOT replacement was less than $30 \%$, when the water content kept constant. The mixture with $30 \%$ IOT content had the greatest slump of $195 \mathrm{~mm}$ and excellent cohesiveness and water retention. This was because the finer IOT powder in the concrete mixture increased the fluidity of the mortar, and thus the resistance to motion of the coarse aggregate decreased. However, the slump value decreased with the increasing of the IOT content when it was more than $30 \%$. This was because too much
IOT with finer size powder could make the concrete mixture thicker. It is also shown in Table 4 that the slump loss of the first 60 min was increased slightly with the increasing of the IOT content.

Table 4: Changes of the workability of the concrete mixture with IOT

\begin{tabular}{|c|c|c|c|c|}
\hline Trial No. & $\begin{array}{c}\text { Slump } \\
\text { value }(\mathrm{mm})\end{array}$ & $\begin{array}{c}\text { Cohesi- } \\
\text { veness }\end{array}$ & $\begin{array}{c}\text { Water } \\
\text { retention }\end{array}$ & $\begin{array}{c}\text { Slump loss } \\
\text { of } 60 \mathrm{~min} \\
(\mathrm{~mm})\end{array}$ \\
\hline NC & 160 & general & general & 50 \\
\hline 10 IOT & 165 & general & general & 55 \\
\hline 20 IOT & 180 & good & good & 55 \\
\hline 30 IOT & 195 & excellent & excellent & 60 \\
\hline 40 IOT & 175 & excellent & excellent & 60 \\
\hline 50 IOT & 130 & poor & good & 65 \\
\hline 60 IOT & 80 & very poor & good & 75 \\
\hline
\end{tabular}

\subsubsection{Bleeding}

The amount of bleeding of concrete with different amounts of IOT versus time is shown in Figure 2. The bleeding tests indicated that the addition of IOT decreases the bleeding capacity and the bleeding rate, which had a positive impact. For example, for the mix with $30 \%$ IOT, the bleeding capacity at $30 \mathrm{~min}$ reduced by $52 \%$ and the bleeding rate by $48 \%$. The bleeding tests also showed that the bleeding rate was bigger within 30 min with an IOT content of less than $30 \%$. The reduction of bleeding rate and bleeding capacity

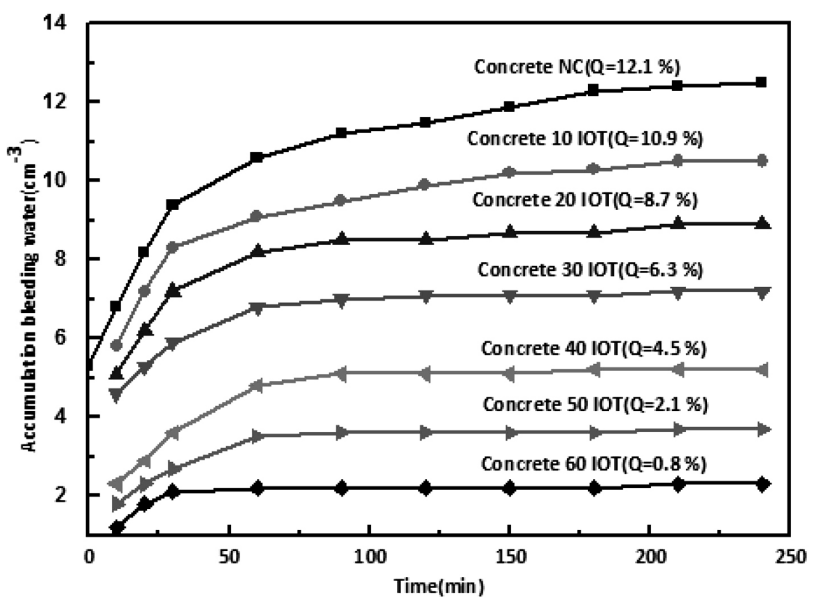

Figure 2: Cumulative bleeding curves of concrete with different IOT contents 
should be attributed to the finer size of IOT with a specific surface, which reduced the content of free water in the system compared with the regular sand.

Considering the slump tests results, when the addition of IOT was more than $30 \%$, it caused an unfavorable influence on the compaction because of the thickness of the fresh concrete. It is clear that a $30 \%$ IOT replacement has a significant effect on improving the workability of the fresh concrete from Table $\mathbf{4}$ and Figure 2. At this level, comparing with the mix without IOT, the slump increased by $22 \%$ and the bleeding capacity decreased by $45 \%$, respectively.

\subsection{Properties of hardened concrete}

\subsubsection{Mechanical properties}

The results of the mechanical property tests on the specimens are shown in Figure 3 and Table 5, and the value is the average of three measurements. It can be seen from Figure 3 that the compressive strength of the $3^{\text {rd }}$ increases as the percentage of IOT increases to $50 \%$, the $7^{\text {th }}$ to $40 \%$, the $28^{\text {th }}$ to $30 \%$, and the $90^{\text {th }}$ to $30 \%$. From Table 5 it is clear that the tensile and flexural strengths at $28 \mathrm{~d}$ increase for the concrete with $30 \%$ IOT, and the tensile-compressive strength ratio nearly showed the same. When the replacement of sand by IOT is $30 \%$, the compressive strength of concrete increases by about $30 \%$ at the age of $28 \mathrm{~d}$. The 28 -days compressive strength and split flexible strength of the hardened concrete specimens all exceeded $35 \mathrm{MPa}$ and $5 \mathrm{MPa}$, respectively, and they reached the maximum when there were $30 \%$ IOT in the mix. When the replacement of IOT was more than $40 \%$, the strength reduced at the age of $(14,28$ and 90) d. This is because of the smaller size of the IOT than the regular fine aggregate. From Table 2, the particles size of the IOT is mostly between $0.300 \mathrm{~mm}$ and $0.150 \mathrm{~mm}$, when that of the regular sand is larger than $0.300 \mathrm{~mm}$, so the IOT can mix with the other component uniformly. The small size of the IOT particles makes the hardened concrete denser by the filling effect, especially for crushed fine aggregate with more large material. Nevertheless, over-adding IOT results in fresh concrete thin even loose. So the strength of the concrete is very seriously affected by the degree of

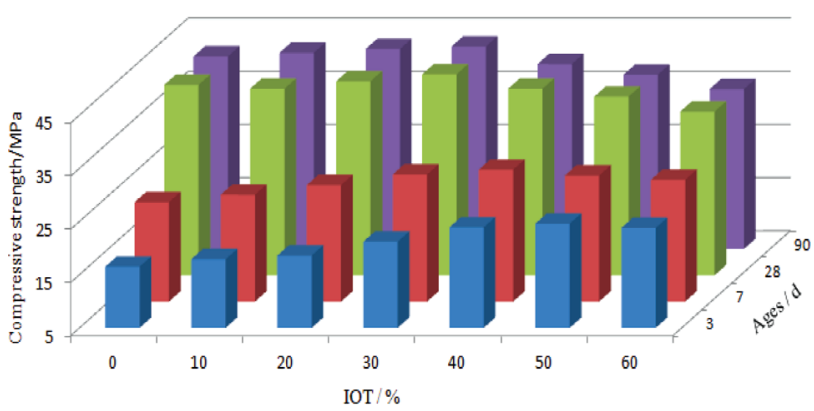

Figure 3: Compressive strength of hardened concrete with different IOT content at the age of $(3,7,28$ and 90$) \mathrm{d}$ its compaction by bad workability, and this can be observed from Figure 4. In the hardened concrete microstructure with $60 \%$ IOT, there are some cracks observed in the SEM.

Table 5: Mechanical properties of harden concrete

\begin{tabular}{|c|c|c|c|c|c|c|c|}
\hline \multirow{2}{*}{$\begin{array}{c}\text { Trial } \\
\text { No. }\end{array}$} & \multicolumn{4}{|c|}{$\begin{array}{c}\text { Compressive strength } \\
(\mathrm{MPa})\end{array}$} & $\begin{array}{c}\text { Tensile } \\
\text { strength } \\
(\mathrm{MPa})\end{array}$ & $\begin{array}{c}\text { Flexural } \\
\text { strength } \\
(\mathrm{MPa})\end{array}$ & $\begin{array}{c}\text { Tensile- } \\
\text { compressive } \\
\text { strength } \\
\text { ratio }\end{array}$ \\
\hline NC & 16.5 & 23.7 & 40.8 & 41.2 & 3.8 & 5.2 & 0.093 \\
\hline 10 IOT & 17.9 & 25.1 & 40.1 & 41.9 & 4.2 & 5.7 & 0.105 \\
\hline 20 IOT & 18.6 & 26.9 & 41.5 & 42.6 & 5.1 & 6.5 & 0.123 \\
\hline 30 IOT & 21.2 & 28.9 & 42.8 & 43.1 & 6.7 & 7.3 & 0.156 \\
\hline 40 IOT & 23.9 & 29.8 & 40.1 & 39.8 & 6.3 & 7.2 & 0.157 \\
\hline 50 IOT & 24.6 & 28.7 & 38.6 & 37.8 & 4.5 & 5.6 & 0.117 \\
\hline 60 IOT & 23.8 & 27.9 & 35.8 & 35.1 & 3.7 & 4.8 & 0.103 \\
\hline
\end{tabular}

\subsubsection{Shrinkage}

The shrinkage results are shown in Figure 5. The values are the average of three samples for each age. The results show that the IOT content of concrete has a detrimental effect on the shrinkage deformation. There is obvious shrinkage deformation increasing in early $28 \mathrm{~d}$ age in spite of the IOT replacement ratio. The gentle trends of shrinkage deformation were observed for the $30 \%$ and $40 \%$ replacement after $28 \mathrm{~d}$, but a further increasing for the $50 \%$. Furthermore, the initial cracking
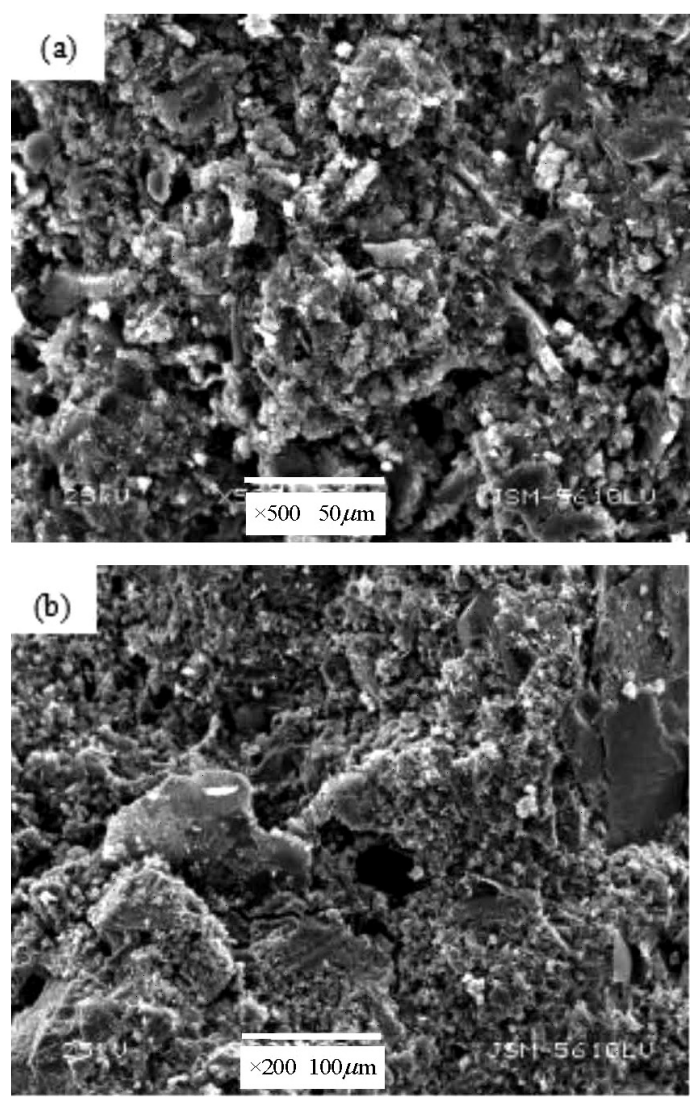

Figure 4: SEM micrographs of the hardened concrete of IOT: a) $30 \%$ and b) $60 \%$ at $28 \mathrm{~d}$ 


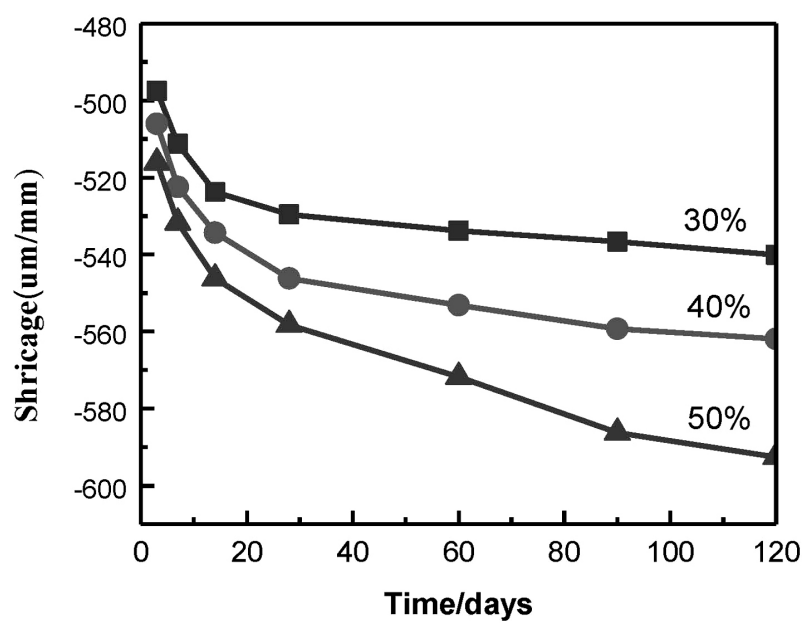

Figure 5: Shrinkage curve of samples with IOT $30 \%, 40 \%$ and $50 \%$ at different time

time was $(48.3,36.8$ and 25.2$) \mathrm{h}$ for IOT $30 \%, 40 \%$ and $50 \%$, respectively. This can be ascribed to two factors: more IOT replacement and finer particles of IOT. On one hand, the former factor can reduce the strength of concrete, which decreases the restriction to shrinkage deformations. On the other hand, the more added water can compensate the finer particles of IOT, which leads to thicker fresh concrete and an increase of the shrinkage deformations for more IOT replacement.

The results of cracking resistance of the concrete with $40 \%$ IOT replacement were listed in Table 6. For the samples with $40 \%$ IOT replacement, the shrinkage value is small, $553.1 \mu \mathrm{m} / \mathrm{m}$, at the age of $60 \mathrm{~d}$. Its initial crack time is $36.8 \mathrm{~h}$, and there is no evident change for the shrinkage value, as well as for the crack number, the width and the length after $28 \mathrm{~d}$. During the whole experiment, only very fine cracks were observed on the surface. All the results showed that the cracking resistance grade of the samples was ascribed to the second grade according to the Chinese national standard of GB50164.

Table 6:Cracking resistance of $40 \%$ IOT replacement

\begin{tabular}{|c|c|c|c|c|c|c|c|}
\hline Items & \multicolumn{7}{|c|}{ Age (days) } \\
\hline & 3 & 7 & 14 & 28 & 60 & 90 & 120 \\
\hline Crack numbers & 1 & 1 & 2 & 2 & 3 & 3 & 4 \\
\hline $\begin{array}{c}\text { Maximum crack width } \\
\text { (mm) }\end{array}$ & 0.1 & 0.2 & 0.3 & 0.8 & 0.9 & 1.0 & 1.1 \\
\hline $\begin{array}{c}\text { Total crack length } \\
\text { (mm) }\end{array}$ & 30 & 35 & 46 & 48 & 68 & 72 & 73 \\
\hline $\begin{array}{c}\text { Weighting crack length } \\
(\mathrm{mm})\end{array}$ & 0.2 & 0.2 & 0.3 & 0.4 & 0.5 & 0.6 & 0.6 \\
\hline $\begin{array}{c}\text { Total cracking area } \\
\left(\mathrm{mm}^{2} / \mathrm{m}^{2}\right)\end{array}$ & 181 & 331 & 577 & 728 & 852 & 876 & 902 \\
\hline
\end{tabular}

\section{CONCLUSIONS}

This study focuses on exploring whether IOT can be used as a fine aggregate replacement for regular sand in concrete. The following conclusions can be drawn:
1) The replacement of some regular sand with IOT can improve the workability of the fresh concrete by compensating the aggregate grading, while the slump and bleeding of fresh concrete was the best with a $30 \%$ replacement of IOT.

2) Due to the small particle size of the IOT, which is less than $300 \mu \mathrm{m}$, the compressive strength of the hardened concrete increases because the IOT powder can fill the small pores existing in the hardened concrete. When the replacement of IOT is $30 \%$, the flex-compression ratio is almost $1 / 6$. Over-adding of the IOT results in some cracks in the hardened concrete microstructure, which decreases its compressive strength.

3) The harden concrete of less than $40 \%$ IOT replacement has good durability because of the high compressive strength to restrict the shrinkage deformations. The cracking resistance of the hardened concrete with $40 \%$ IOT replacement is ascribed to the second grade according to the Chinese national standard of GB50164.

4) The IOT can be utilized to prepare concrete as fine aggregate with good workability of fresh concrete and good performance of the hardened concrete, and the maximum amount is a $40 \%$ replacement of regular sand.

\section{Acknowledgments}

This work was financially supported by the Natural Science Foundation of HuBei Province of China (2017CFB582); the Science-Technology Innovative Research Team for Excellent Middle-aged and Young Scientist in Higher Education Institutions of Hubei Province of China (T201626); The National Nature Science Foundation of China (51801058).

\section{REFERENCES}

${ }^{1}$ F. Zhao, Existing problem analysis to the comprehensive utilization of domestic metallic ore tailings, Mod. Min., 12 (2015) 56-59, doi:10.3969/j.issn.1674-6082.2015.04.038

${ }^{2}$ M. Mohanty, N. K. Dhal, P. Patra, B. Das, P. S. R. Reddy, Phytoremediation: a novel approach for utilization of iron-ore wastes, 206 (2010) 29-47, Rev. Environ. Contam. Toxicol., doi:10.1007/9781-4419-6260-7_2

${ }^{3}$ M. K. Ghose, P. K. Sen, Characteristics of iron ore tailing slime in India and its test for required pond size, Environ. Monit. Assess., 68 (2001) 51-61, doi:10.1023/a:1010782822753

${ }^{4}$ M. A. Onitiri, E. T. Akinlabi, Effects of particle size and particle loading on the tensile properties of iron-ore-tailing-filled epoxy and polypropylene composites, Mech. Compos. Mater., 52 (2017) 6 , 817-828, doi:10.1007/s11029-017-9633-4

${ }^{5}$ S. Ullas, B. Reddy, K. Rao, Characteristics of masonry units from iron ore tailings, Inter. Confer. Sustain. Built Environ., 2010, 108-114

${ }^{6}$ T. I. Ugama, S. P. Ejeh, Iron ore tailing as fine aggregate in mortar used for masonry, Int. J. Adv. Eng. Technol, 7 (2014) 2, 1170-1178

${ }^{7}$ A. Shettima, M. Hussin, Y. Ahmad, J. Mirza, Evaluation of iron ore tailings as replacement for fine aggregate in concrete, Constr. Build Mater., 120 (2016) 72-79, doi:10.1016/j.conbuildmat.2016.05.095

${ }^{8}$ N. Kumar, Utilization of iron ore tailings as replacement to fine aggregates in cement concrete pavement, Int. J. Res. Eng. Technol., 3.7 (2014) 369-376, doi:10.15623/ijret.2014.0307063 
${ }^{9}$ Z. Zhu, B. Li, M. Zhou, The Influences of iron ore tailings as fine aggregate on the strength of ultra-high performance concrete, Adv. Mater. Sci. Eng., 4 (2015) 1-6, doi:10.3969/j.issn.1001-702X.2013. 04.009

${ }^{10}$ X. Huang, R. Ranade, W. Ni, V. Li, Development of green engineered cementitious composites using iron ore tailings as aggregates, Constr. Build Mater., 44 (2013) 757-764, doi:10.1016/j.conbuildmat.2013.03.088

${ }^{11} \mathrm{~S}$. Zhao, J. Fan, W. Sun, Utilization of iron ore tailings as fine aggregate in ultra-high performance concrete, Constr. Build Mater., 50 (2014) 540-548, doi:10.1016/j.conbuildmat.2013.10.019

${ }^{12}$ X. Huang, W. Ni, K. Li, Development of engineered cementitious composites containing iron ore tailing powders, Chin. J Eng., 37 (2015) 11, 1491-1497, doi:10.13374/j.issn2095-9389.2015.11.015

${ }^{13}$ Y. Hou, Comparison of effect of iron tailing sand and natural sand on concrete properties, Key Eng. Mater., 599 (2014) 11-14, doi:10.4028/www.scientific.net/KEM.599.11

${ }^{14}$ K. Shetty, G. Nayak, V. Vijayan, Effect on red mud and iron ore tailings on the strength of selfcompacting concrete, Eur. Sci. J, 10 (2014) 21, 168-176, doi:10.19044/esj.2014.v10n21p\%p

${ }^{15}$ S. Jian, L. Yuan, L. Yang, H. Tan, X. Li, G. Bao, Study on sintered wall materials made use of iron tailings and waste rock, Adv. Mater Res., 5 (2011) 243-249, doi:10.4028/www.scientific.net/AMR. 243-249.7036
${ }^{16}$ M. Zhou, Z. Zhu, B. Li, J. Liu, Volcanic activity and thermal excitation of rich-silicon iron ore tailing in concrete, J. Wuhan Univ. Technol.-Mater. Sci. Ed., 32 (2017) 2, 365-372, doi:10.1007/ s11595-017-1604-z

${ }^{17}$ K. Behera, B. P. Bose, M. K. Mondal, Production of construction bricks using iron ore tailings and clay, Waste Resour. Manag. Effici., 9 (2018) 583-596, doi:10.1007/978-981-10-7290-1_49

${ }^{18}$ C. Li, H. Sun, J. Bai, L. Li, Innovative methodology for comprehensive utilization of iron ore tailings, J. Hazard. Mater., 174 (2010) 1-3 71-77, doi: 10.1016/j.jhazmat.2009.09.018

${ }^{19}$ I. Licskó, L. Lois, G. Szebényi, Tailings as a source of environmental pollution, Water Sci. Technol., 39 (1999) 10, 333-336, doi:10.1016/ S0273-1223(99)00295-4

${ }^{20} \mathrm{https} / / / \mathrm{www}$. researchgate.net/publication/308740260, 01.01.2016

${ }^{21}$ C. Yang, C. Cui, J. Qin, X. Cui, Characteristics of the fired bricks with low-silicon iron tailings, Constr. Build. Mater., 70 (2014) 36-42, doi:10.1016/j.conbuildmat.2014.07.075

${ }^{22}$ F. Wang, R. Yang, Y. Lei, X. Zhang, Y. Chen, Study on preparation of functional wall material with iron tailings, J. Hubei Polytech. Univ., 29 (2013) 128-49, doi:10.1016/j.conbuildmat.2014.07.075

${ }^{23}$ Z. Yu, H. Li, Y. Jiang, Y. Chen, Study on the preparation of light heat-insulation wall material with iron tailings, New Build. Mater., 4 (2013) 30-33, 36, doi:10.3969/j.issn.1001-702X.2013.04.009 